\title{
OPENING THE PANDORA'S BOX? TRADE OPENNESS AND INFORMAL SECTOR GROWTH
}

\author{
Amit Ghosh \\ Saumik Paul* \\ Department of Economics \\ Claremont Graduate University \\ 170 East Tenth Street. \\ Claremont, CA 91711 \\ USA.
}

\begin{abstract}
This paper constructs a labor transition model combining the features of job loss and job creation in the formal sector of an economy. The theoretical model examines the impact of trade liberalization on net job transition from formal to informal sector. In the light of our model we establish certain pre-conditions based on simulations under which trade liberalization is accompanied by rising informal sector. The model outcome conforms to the empirical evidence of rising informality with openness which we find in 18 Central Eastern European (CEE) and Former Soviet Union (FSU) countries.
\end{abstract}

* Corresponding author. E-mail: saumik.paul@cgu.edu 


\section{Introduction}

Most economies around the globe are characterized by the presence of an informal sector, which does not comply with government regulations, but contributes to the total volume of goods and services in a country ${ }^{1}$; its size varying among nations, been relatively greater for developing economies than developed economies ${ }^{2}$. We find empirical evidence from 18 Central and East European (CEE) and former Soviet Union (FSU) countries that trade openness is positively related with the informal share of the gross domestic product (GDP) ${ }^{3}$. In this paper we build a theoretical model to analyze the impact of trade openness on the relative growth of the formal and informal share of total labor force. Our objective is to study the impact of trade reforms on labor market, particularly the degree of growth of informal labor share given certain economic preconditions.

The existing literature ${ }^{4}$ on informal sector can be classified into two broad strands. One group stresses on definition and measurement of informal sector and the other deals with policy issues related to informal sector. Policy issues can further be branched according to different approaches, such as new institutional or transaction cost, macroeconomic general equilibrium models etc. Macroeconomic general equilibrium models incorporating informal labor market (Agenor and Montiel, 1996; Carruth and Oswald, 1981; Marjit and Beladi, 2001; Rauch, 1991 etc) and computable general

\footnotetext{
${ }^{1}$ This is a very lucid way to explain informal sector, which suffers from significant definitional, and measurement problems.

${ }^{2}$ Scheneider and Enste (2000) give comprehensive measures of informal sector in countries from different regions around the globe.

${ }^{3}$ We used Kaufman and Kaliberda (1996) measurement of informal sector for empirical purpose

${ }^{4}$ See Gerxhani (2003) for a detail literature survey on informal sector
} 
equilibrium (CGE) models (Schaefer, 2002; Gibson, 2005 etc) have also been used most extensively to derive macro policies related to informal sector.

The last two decades has witnessed the episode of trade reforms and liberalization in almost every corner of the world. Most of the existing work relating trade reforms with labor force has focused primarily on the wage differential between skilled and unskilled labor ${ }^{5}$. Feenstra and Hanson (1997), Harrison and Hanson (1999) show that trade reforms and liberalization led to rising wage inequality in Mexico ${ }^{6}$. They analyze the impact of trade liberalization on factor prices of both skilled and unskilled workers in the formal labor sector. Yabuuchi et al. (2005) introduces an informal sector in the Harris-Todaro model, which provides industrial input to the formal sector, but their conclusion does not include the direct impact of trade reforms on informal labor sector.

Agenor (2005) theoretically argues that if labor unions care sufficiently about skilled wage and if the degree of openness is sufficiently high, unemployment of both skilled and unskilled labor may actually fall in the long run. Marjit (2003) argues that the informal sector itself has labor-intensive and capital-intensive sub-segments. If economic reforms hurt the capital-intensive formal sector, it also leads to a contraction in the capital-intensive informal segment while employment and real wages rise in labor intensive part of the informal sector. A further analysis by Marjit and Kar (2001) provides an interesting result why mobility of capital is essential for making the process

\footnotetext{
${ }^{5}$ If trade between developed and developing nation's leads to the North (i.e. developed) specializing in skill-intensive goods than it will raise the wages of the skilled labor in its country. The South (developing), specializes in goods which is less skill intensive compared to the North but is more skilled labor intensive compared to its rest of the economy. Thus wages of skilled labor rises in South also, leading to a growing wage inequality within both North and South.

${ }^{6} \mathrm{An}$ increase in the relative wage gap between white and blue-collared workers with trade has also been found for Australia, Japan, Sweden \& the U.K. by Freeman \& Katz (1994), Katz et al. (1999); and for Hong Kong and the U.K. by Hsieh \& Woo (1994), Anderton \& Brenton (1997).
} 
of reform a success. A greater degree of capital mobility helps to increase informal wage in case of contraction in the formal sector.

In a recent study, Goldberg and Pavcnik (2003) have analyzed the impact of trade liberalization on the informal labor force for two Latin American countries - Brazil \& Colombia. They do not find any positive empirical results of trade liberalization, measured by reduction of tariff rates, on informality. In both of these countries trade reforms were simultaneously accompanied by labor market reforms, reducing the costs of firing and hiring formal workers. This introduction of more flexibility in the labor market contributed to a rise in the hiring of a formal workforce.

Our theoretical argument differs from the existing literature in two ways. First we forward a partial equilibrium analysis of labor market, considering both formal and informal share of labor. Second we do not consider wage differential as a source of ruralurban migration and growth of informal labor sector. Most of the existing literature is based on the impact of trade reforms on wage rate. We model the labor transition between formal and informal sector in terms of job loss and gain in only formal sector as a result of trade reforms. We consider the informal sector as the residual of the formal sector from total labor force, and find the impact of trade reforms on the size of informal share of total labor force.

The analysis of informal sector becomes particularly important when one relates trade with welfare. Existing literature shows growing informal sector increases the wage dispersion or income inequality. Studies on formal-informal interactions in developing countries claim that economic reforms increase the level of informal activity ${ }^{7}$. Our main

\footnotetext{
${ }^{7}$ See Kar and Marjit (2001), Marjit (2003).
} 
focus here remains to forward some policy analysis discussing cases when a country can benefit most out of trade reforms or openness, keeping the informal labor growth low.

We find the level of the informal share of gross domestic product to be positively related with trade liberalization measures in 18 Central and East European (CEE) and Former Soviet Union (FSU) countries. This empirical case study is given in section II. This motivates us to develop our theoretical model in section III, which analyzes the relative expansion of both formal and informal labor shares of the economy, in both the absence and presence of trade liberalization. In section IV we provide a brief policy discussion based on simulated results of our theoretical model and some concluding remarks thereafter.

\section{Panel evidence from CEE and FSU Countries}

One of the prime concerns of our empirical analysis has been the reliability of data on the informal sector. We find Kaufman and Kaliberda (1996) measure of informal sector as a percentage of gross domestic product (GDP), as the most reliable source on 18 CEE and FSU countries ${ }^{8}$. They measure the extent of a country's informal economy by the difference between the official GDP growth rate and a country's growth rate of electricity usage. We use their measure in estimating the informal economy's size. Trade liberalization in our empirical model is captured by three typical measures of trade openness - exports of goods and services as percent of GDP, imports of goods and services as percent of GDP and combined exports plus imports (often termed as 'trade')

\footnotetext{
${ }^{8}$ Other recent work, which has used this measure, includes Ihrig and Moe (2004).
} 
of goods and services as percent of GDP ${ }^{9}$. We control for foreign direct investment (FDI), net inflows as a percent of GDP, urban share of total population and government final consumption expenditure as a percentage of $\mathrm{GDP}^{10}$. Descriptive statistics of all these variables are given in table 1.

\section{[Table 1]}

We estimate a panel of 18 CEE and FSU countries for the period 1990-1995. This is shown as equation $(\mathrm{M})$ below.

$I N F O R M A L_{\mathrm{i}}^{\mathrm{t}}=\mathrm{a}_{0}+\mathrm{a}_{1} O P E N_{\mathrm{i}}^{\mathrm{t}}+\mathrm{a}_{2} F D I_{\mathrm{i}}^{\mathrm{t}}+\mathrm{a}_{3} U R B A N_{\mathrm{i}}^{\mathrm{t}}+\mathrm{a}_{4} G O V_{\mathrm{i}}^{\mathrm{t}}+\mathrm{a}_{5} C_{\mathrm{i}}+\varepsilon_{\mathrm{i}}^{\mathrm{t}}$

In equation. (M) INFORMAL ${ }_{\mathrm{i}}^{\mathrm{t}}$ refers to the informal share of GDP in $\mathrm{i}^{\text {th }}$ country at period t, where $\mathrm{i}$ runs from 1 to 18 and t lies in the span of 1990 to 1995 , both inclusive. In similar way OPEN refers to the trade openness measures as a proxy for trade liberalization, FDI represents the foreign direct investment, net inflows as a percent of GDP, URBAN implies urban share of total population, GOV measures the government final consumption expenditure as a percent of GDP and finally we use $C_{\mathrm{i}}$ dummy to capture the country fixed effect. We do not consider time fixed effect as there is much lesser variation expected over time in each of these 18 countries whereas the variation across the countries is comparatively much higher.

\footnotetext{
${ }^{9}$ Alternative measures that could have been used were average tariff rates or tariff revenue to imports ratio; however such data for these economies were not available. As such we use the trade-to-GDP ratios.

${ }^{10}$ Data sources are given in appendix 1.
} 
We run three ordinary least squares regressions considering three alternate specifications of the base model (M) with the three measures of trade openness. Empirical outcomes are shown in table 2. In the first column we use trade (as percent of GDP), second export (as percent of GDP) and third column import (as percent of GDP). These are shown as model 2.1, 2.2 and 2.3 in table 2, respectively. We find all three specifications of the trade openness measures are positive and statistically significant at 95 percent confidence level with informal share of GDP. We also find robust statistical support of FDI inflows being positive and significant in affecting the informal economy's size. The coefficient for urban labor force significantly increases the informal share of GDP, supporting the existing claim in literature that informality tend to grow faster in urban areas ${ }^{11}$. The government final consumption expenditure is found to be positive but insignificant. Overall we find strong statistical evidence that trade liberalization or openness significantly increases the informal share of GDP after controlling for the other relevant factors like urban share of total population, FDI inflows etc.

[Table 2]

These robust empirical findings motivate us further into developing a theoretical framework where we analyze in detail the growth of both formal and informal labor shares of a country's total labor as it makes the transition from a closed economy to an open one. Before we proceed to our next section, we make one realistic assumption that informal share of GDP behaves in accord with informal share of total labor. This is just to

\footnotetext{
${ }^{11}$ For detailed discussion see Portes et al. (1987).
} 
clarify the probable confusion one might have since our empirical support was based on informal share of GDP, but we model informal share of total labor.

\section{Theoretical Model:}

We start with a typical 2-economy model where one single economy, we call it home trades with the rest of the world. Let $A \subset R_{+}$be the ordered set of $\mathrm{n}$ different sectors or industries in home country, where formal production takes place ${ }^{12}$. Thus home country is involved in producing $\mathrm{n}$ different commodities. The relative prices of these $n$ industries compared to the rest of the world is given by the following inequality

$$
p_{1}<p_{2}<p_{3}<\ldots \ldots . .<p_{n}
$$

Since $A$ is an ordered set, we can order the sectors as $A_{1}, A_{2}, \ldots . A_{n}$ where home country has highest comparative advantage in sector $A_{l}$ and highest comparative disadvantage in sector $A_{n}$. Typical trade theory suggests home country will export commodities it has comparative advantage on, and import on which it has comparative disadvantage, if trade takes place. Lets assume $A_{C A} \subset R_{+}$be a sub set of $A$ consisting of $s$ comparatively advantageous sectors $A_{1}, A_{2}, \ldots A_{s}$, and $A_{C D} \subset R_{+}$be another sub set of $A$ consisting of $n-s$ disadvantageous sectors $A_{s+1}, A_{s+2}, \ldots A_{n}$ in the home country. These industries produce their output using domestic labor force ${ }^{13}$ and other factors of production.

Pure trade theory models like Ricardian or Hecscher-Ohlin are based on classical foundations i.e. there is full employment of labor. Since our purpose is to analyze the

\footnotetext{
12 Production which is accountable by the government or enters into national account calculations.

${ }^{13}$ For the sake of simplification we assume that home country does not use foreign labor.
} 
impact of liberalization on the informal economy, we assume there is less than full employment in home ${ }^{14}$.

The domestic labor force of the economy comprises of the aggregate formal workforce as well as the informal labor force ${ }^{15}$. In present period of time $t$, we have

$$
L^{t}=L_{F}^{t}+L_{L}^{t}
$$

Let $k$ be the proportion of the economy's labor force in the formal sector and $(1-k)$ in the informal sector. Thus formal laborers work in the formal sectors and informal laborers work in the informal sectors.

$L^{t}=k L^{t}+(1-k) L^{t}$

We have already defined formal sector consisting of comparatively advantageous or export sectors (s) and comparatively disadvantageous or import competing sectors $(n-s)$. We assume formal share of total labor force is absorbed in either export or import competing sectors. Since capital has no role to play in our model for simplicity we can simply write the output-labor mapping in period $t$ as $A_{C A}^{t}=f_{C A}\left(L_{C A}^{t}\right)$ where $f_{C A}: R^{l} \rightarrow$ $R^{l}+$ and $A_{C D}^{t}=f_{C D}\left(L_{C D}^{t}\right)$ where $f_{C D}: R_{+}^{1} \rightarrow R_{+}^{1}$. Thus,

$$
\begin{aligned}
L^{t} & =L_{C A}^{t}+L_{C D}^{t} \\
& =\alpha k L^{t}+(1-\alpha) k L^{t}
\end{aligned}
$$

with $0<\alpha<1$

where $\alpha$ is the proportion of the formal labor force in the sectors with comparative advantage and $(1-\alpha)$ been the proportion in the comparative disadvantageous sectors.

\footnotetext{
${ }^{14}$ Since informal sector's output is not taken into consideration in estimating a nation's GDP, from national income accounting point of view informal sector is considered part of the unemployment labor pool.

${ }^{15}$ For sake of simplicity we assume that home country does not use foreign labor.
} 


\section{(a) No trade liberalization}

Initially we consider the situation where the home country does not embark on the route of trade liberalization. It imposes trade barriers throughout the economy in order to prevent the import competing sectors from external competition i.e. it is a predominantly closed economy. Over time the economy-wise industries expand. We first look at the demand side of labor market. Since the sectors in which home country has a comparative advantage are the ones in which it is an efficient producer, we assume the rate of expansion of $A_{C A}, \gamma$ is higher than the rate of expansion of $A_{C D}, \delta$.

Thus, $\gamma>\delta$.

In period $t+1$ we have,

$L_{C A}^{t+1}=(1+\gamma) \alpha k L^{t}$

$L_{C D}^{t+1}=(1-\alpha)(1+\delta) \alpha k L^{t}$

with $0<\gamma, \delta<1$

The size of the overall formal labor force in period $(t+l)$ is now given by

$L_{F}^{t+1}=(1+\gamma) \alpha k L^{t}+(1+\delta)(1-\alpha) k L^{t}$

The overall job creation in the formal sector over time is given by

$L_{F}^{t+1}-L_{F}^{t}=\gamma \alpha k L^{t}+(1-\alpha) \delta k L^{t}$

Turning to the supply of labor in the economy, let $g$ be the growth rate of the overall labor force. In period $(t+1), g L^{t}$ be the new labor force joining the economy. Also let $m$ be the fraction of the new labor force absorbed in the formal sector, in terms of the new jobs created there as shown above. The remaining fraction $(1-m)$ of the new entrants in the job market goes to the informal sector. Moreover, let $\mu$ be the fraction of 
marginal informal workers who attains the skills required to work in the formal sector in period $t$. They also enter the formal sector at period $(t+1)$. In this model, the supply of labor in the formal sector is constrained by the demand for labor. We treat the informal sector as the residual of the formal labor demand from total labor supply in any period. The size of the informal economy in period $(t+1)$ is given by

$L_{I}^{t+1}=(1-\mu)(1-k) L^{t}+(1-m) g L^{t}$

The additional jobs created in the formal economy absorb the combined supply of labor coming from the new entrants in the job market and the marginal informal workers. Thus, equating the new demand and supply of labor in $(t+1)^{\text {th }}$ period we have

$\alpha \gamma k L^{t}+(1-\alpha) \delta k L^{t}=\mu(1-k) L^{t}+m g L^{t}$

The optimal size of the formal economy relative to the entire economy is given by

$k^{*}=\frac{m g+\mu}{\alpha \gamma+(1-\alpha) \delta+\mu}$

\section{(b) Trade liberalization}

Next we consider the situation when the home country opens up its economy by trading with rest of the world. We can view this trade liberalization in the form of reduction and removal of trade impediments like tariffs, quotas etc throughout all sectors of the economy. With liberalization of the economy, the sectors in which home has its comparative advantage can export its products to the rest of the world, while the import competing sectors will face foreign competition and will contract. The expanding export sectors will lead to an increase in labor demanded while the contracting import 
competing sectors will cause a decline in labor demand. The now labor force in sectors with comparative advantage and disadvantage in period $(t+1)$ are given as follows

$L_{C A}^{t+1}=\left(1+\gamma_{t l}\right) \alpha k L^{t}$

$L_{C D}^{t+1}=(1-\alpha)\left(1-\delta_{t l}\right) k L^{t}$

where again $0<\gamma_{t l}, \delta_{t l}<1$

Trade liberalization aims to promote an economy's exports to the world, creating employment opportunity and growth. Export promotion in the industries in which a nation possesses comparative advantage will lead to the expansion of the sector at a rate higher than if the sector only caters to the domestic internal market. As such we make the following assumption ${ }^{16}$.

$\gamma_{t l}>\gamma$

The formal labor force with trade liberalization in period $(t+1)$ is given by

$L_{F}^{t+1}=\left(1+\gamma_{t l}\right) \alpha k L^{t}+\left(1-\delta_{t l}\right)(1-\alpha) k L^{t}$

The net employment creation in the formal sector is given by

$L_{F}^{t+1}-L_{F}^{t}=\gamma_{t l} \alpha k L^{t}-(1-\alpha) \delta_{t l} k L^{t}$

As in the earlier section, we assume that $g$ be the growth rate of the overall labor force, with $m_{t l}$ fraction of the new labor force absorbed in the formal sector and $\mu_{t l}$ be the marginal workforce that makes the transition from the informal to the formal sector. As such in the post-liberalization period the informal labor share of home country is comprised of three components. First, the existing informal workforce not absorbed by the formal comparative advantageous sectors. Second, the new labor force that does not

\footnotetext{
${ }^{16}$ In a closed economy, an industry's productive capacity is constrained by its Production possibility frontier. But trade liberalization allows to produce beyond its PPF.
} 
find employment in the formal expanding sector. Finally, the labor force released from the shrinking formal comparative disadvantageous industries.

$$
L_{I}^{t+1}=\left(1-\mu_{t l}\right)(1-k) L^{t}+\left(1-m_{t l}\right) g L^{t}+\delta_{t l} k(1-\alpha) L^{t}
$$

Analogous to the earlier section, in equilibrium, the new formal jobs created equals the labor supplied from the new entrants and the informal sector ${ }^{17}$. The optimal proportion of the formal economy in country A is

$\alpha \gamma_{t l} k=\mu_{t l}(1-k)+m_{t l} g$

$k_{t l}^{*}=\frac{m_{t l} g+\mu_{t l}}{\alpha \gamma_{t l}+\mu_{t l}}$

\section{(c) Comparison of formal labor share with and without liberalization}

We have already obtained the optimal share of formal and informal sector resulting from labor market equilibrium conditions. Now we derive under what circumstances trade liberalization leads to a rising informal economy. From eqs. 9 and 9a, $k^{*}>k_{t l}^{*}$ if $\frac{m g+\mu}{\alpha \gamma+(1-\alpha) \delta+\mu}>\frac{m_{t l} g+\mu_{t l}}{\alpha \gamma_{t l}+\mu_{t l}}$

or $k^{*}>k_{t l}^{*}$ if $\delta<\left(\frac{1}{1-\alpha}\right)\left[\frac{(m g+\mu)\left(\alpha \gamma_{t l}+\mu_{t l}\right)}{\left(m_{t l} g+\mu_{t l}\right)}-\alpha \gamma-\mu\right]=\bar{\delta}$

For modeling simplicity we assume $m_{t l}=m ; \mu_{m l}=\mu$, that is the fraction of new labor force absorbed in the formal sector is same both with and without trade liberalization and the marginal informal workforce transits from informal to formal sector at the same rate with and without trade liberalization.

$\delta<\frac{\alpha\left(\gamma_{t l}-\gamma\right)}{1-\alpha}$

\footnotetext{
${ }^{17}$ However, unlike the situation when there was no trade liberalization, here the new jobs are demanded by only the export sectors while the import competing, comparative disadvantageous sectors contract.
} 
Thus we find whether trade liberalization leads to higher informal sector growth depends on how the comparatively disadvantageous sectors grow under no trade. If the expansion of the $A_{C D}$ exceeds some threshold level given as $\bar{\delta}$, then our model predicts insignificant increase in informal sector a results of trade liberalization and vice-versa. In section II we found CEE and FSU countries experiencing increasing informal sector as a results of trade openness. In the light of our theoretical model it can be inferred that these countries have had lower growth in $A_{C D}$ sectors.

\section{Discussion}

Our theoretical model is aimed to capture future possibilities of informal sector growth of a country given certain economic pre-conditions based on the structural parameters of our model. We perform simulations by varying the parameter values to forecast formal and informal labor logistic. The purpose of this exercise is twofold. First, to project the composition of the formal and informal sectors, as well as their relative shares both without and with trade liberalization and second, to use them for policy issues like when and why trade reforms can benefit a country most with lower informal labor growth.

[Table 3]

The initial parameters for the baseline simulations are given in table 3. The average size of the informal sector during 1990-95, for the countries in our empirical analysis was $25 \%$. We use $k=.75$ as the initial share of formal sector. The average unemployment rate 
during the same period for these nations was between 6 to $8 \%$. Trade liberalization leads to a contraction of the comparative disadvantageous sectors and hence job loss. As such we consider the value of $\delta_{t l}$ to be .08 . The percent of the new labor force joining the formal sectors can be assumed to follow the existing share of the overall formal economy, thus $m=.75$ and $g$, the growth rate of the labor force is given by actual average rate of growth of population in these countries. The initial value for $\alpha$ is considered to be .67. This means the home country in our theoretical model has comparative advantage in two-thirds of total existing sectors in the economy.

Graphs 1-6 shows the simulated projections for the informal and formal labor force along with their composition ${ }^{18}$. Table 4 provides summary results for all the simulations performed.

\section{[Table 4]}

Graph 1.3 depicts that the formal sector share declines with liberalization while the informal sector share rises. The rate of expansion of the formal comparative advantageous sectors with liberalization is less than without. Developing nations when they liberalize look to promote their exports in developed markets. But if there are barriers to entry in foreign markets, then the external demand driven employment expansion does not materialize, leading to rising informality. The export sectors of LDCs are often the import competing sectors for the developed nations. If these industries are protected by governments of developed nations in the form of subsidies then for

\footnotetext{
${ }^{18} \mathrm{We}$ do not present the results for all the simulation graphs for purpose of brevity but are available from the authors upon request.
} 
developing nations, it is a loss of potential market and hence jobs ${ }^{19}$. Graph 3.1-3.3 shows the situation where the formal sectors shrink and informal sector rises at a rapid rate. This implies that the lower the number of industries in which a country has a comparative advantage, the greater will be the rise in informality with liberalization. Simulations by varying the percent of the new labor force joining the formal sector shows that higher these ratios less is the rise in share of the informal sector. Graphs 5, 6 show the situation by varying the fraction of transformation of informal workers to the formal sectors and the growth rates. The higher the percent of informal labor that can be absorbed in the formal sector the lower is the "residual" remaining.

\section{Conclusion.}

Recent empirical evidences pose considerable ambiguity on the relationship between pro-openness trade reforms and income inequality reduction (Easterly, 2001; Edwards, 1997). Numerous studies looked at this issue from various angles, with different approaches. Our primary focus has been to use a relatively narrower policy perspective related to informal sector as a tool to serve the purpose of a broader aspect of trade and growth.

We find empirical evidence from $18 \mathrm{CEE}$ and FSU countries that trade liberalization significantly increases the informal sector share of GDP. We acknowledge the fact that our measure of informality is the informal sector's contribution to the GDP as taken from Kaufman-Kaliberda (1996); and not the proportion of labor force in the informal sector, which we used, in our theoretical model. This does not affect the results

\footnotetext{
${ }^{19}$ Subsidies provided by the EU to their agricultural workers, or blockades to entry for food products like shrimps on safety, health standard measures which create an unequal playing field for developing nations export industries is a factual counterpart of this simulation exercise.
} 
to a great extent, as informal share of total labor force and informal share of GDP go hand in hand.

In our theoretical model we decompose an economy's industries into ones in which it has comparative advantage (disadvantage) relative to the rest of the world, and show the change in the size of the formal (informal) labor force with and without liberalization. We make the assumption that the labor force released from the shrinking import competing sectors as a result of trade, goes entirely to the informal sector i.e. we do not consider direct labor movement between comparative advantageous and disadvantageous sectors. There is a time lag, which can be thought of as job search or job training. A share of that labor force comes back to formal advantageous as marginal informal workers possessing enough skills to join formal sector.

For developing countries, trade liberalization opens up opportunities to accelerate their growth process and reduce unemployment. This paper presents a theoretical model showing the circumstances under which trade liberalization leads to an increase in informal labor force. Notwithstanding the adverse consequences of liberalization, for policy makers the challenge is not in turning away from opening up the economy, but in controlling the growth of the informal sector.

Based on our theoretical model for countries which have a comparative advantage in very few industries, as in many less developed countries, liberalization may lead to more job losses. Finally, as shown by simulation cases 4 and 6 , countries need to invest in higher education and technical, professional training for their workforce, so that with the onset of liberalization, the new workforce is ready to join the formal sector. 
The model developed in this paper can further be extended in several directions. We can analyze labor transition based on sectoral comparative advantage (disadvantage) in the formal sectors under a general equilibrium framework. Here we do not consider labor or capital intensive segments within the informal sector. Introduction of this can enable us to ascertain the impact of trade liberalization on sector-specific informal labor force. Moreover, a further extension of this framework can be by introducing trade liberalization at differential rates of reduction of barriers for different sectors.

\section{ACKNOWLEDGEMENTS:}

The authors would like to thank the helpful suggestions and comments provided by Arthur Denzau, Ramkishen Rajan and Thomas Willett. The views expressed are those of the authors. The usual disclaimer applies. 


\section{References:}

Agenor, P (2005) Fiscal adjustment and labor market dynamics in an open economy, Journal of Development Economics 76, 97-125.

Agenor, P and P. Montiel (1996) Development Macroeconomics, Princeton, NJ: Princeton University Press.

Anderton, B. and Brenton, P. (1997) Outsourcing and Low-Skilled Workers in the U.K. National Institute of Economic and social Research, London, (mimeo).

Autor, D. Katz, F. and Krueger, A.B. (1999) Computing Inequality: Have Computers Changed the Labor Market?, Quarterly Journal of Economics, 113, 1169-1213.

Beladi, H., Yabuchi, S. and Wei, G (2005) Foreign Investment, Urban Unemployment, and Informal Sector, Journal of Economic Integration, 20, 123-138.

Beladi, H and Sugata M. (2001) The Stolper-Samuelson Theorem in a Wage Differential Framework, The Japanese Economic Review 53, 177-181.

Carruth, A and A. Oswald (1981) The Determination of Union and Non-union wage rates, European Economic Review 16, 285-302.

Easterly, W. (2001) The lost decades: explaining developing countries' stagnation in spite of policy reform 1980-1998, Journal of Economic Growth, 6, 135-157.

Edwards, S. (1997) Trade policy, growth, and income distribution, American Economic Review, 87, 205-210.

Feenstra, R. and Hanson, G. (1997) Foreign direct Investment and relative wages: evidence from Mexico's maquiladoras, Journal of International Economics, 42, 371-394.

Freeman, R. and Katz, L. (1994) Rising Wage Inequality: The United States vs. Other Advanced Economies., in Working Under Different Rules (ed) R. Freeman, Russell Sage, New York, pp. 2962.

Gerxhani, Klarita. (2004) The Informal Sector in Developed and Less Developed Countries: A Literature Survey, Public Choice 120: 267-300

Gibson, Bill (2005) The Transition to a Globalized Economy: Poverty, Human Capital and the Informal Sector in a Structuralist CGE Model, Journal of Development Economics 78: 60-94.

Goldberg, P. and Pavcnik, N. (2003) The response of the informal sector to trade liberalization, Journal of Development Economics, 72, 463-496.

Harrison, A. and Hanson, G (1999) Who gains from trade reforms? Some remaining puzzles, Journal of Development Economics, 59, 125-154.

Hsieh, C.T. and Woo, K.T. (1999) The Impact of Outsourcing to China on Hong Kong's Labor Market. Princeton University. (mimeo) 
Ihrig, J. and Moe, K.S. (2004) Lurking in the shadows: the informal sector and government policy, Journal of Development Economics, 73, 541-557.

Johnson, S., Kaufman, D. and Shleifer, A (1997) The unofficial economy in transition Brookings Papers on Economic Activity, July, Washington D.C.

Kar, S and Sugata Marjit (2001) Trade Reform, Internal Capital Mobility and Informal Wage, Mimeo, Center for Studies in Social Sciences, Kolkata.

Kaufman, D and Kaliberda, A. (1996) Integrating the Unofficial Economy into the dynamics of Post-Socialist Economies. A framework for analysis and evidence, in Economic Transition in Russia and the New States of Eurasia (Ed.) B. Kaminski, Sharpe, New York.

Kuchta-Helbling, C.(2000) Barriers to Participation: The Informal Sector in Emerging Economies Center for International Private Enterprise staff paper.

Marjit (2003) Economic reform and informal wage - general equilibrium analysis, Journal of Development Economics 72: 371-378.

Portes, Alejandro and Saskia Sassen-Koob (1987) Making it underground: Comparative material on the informal sector in western market economies. American Journal of Sociology. 93: 30-61

Rauch, James (1991) Modeling the informal sector formally, Journal of Development Economics 35: 33-47.

Schaefer, K (2002) Capacity Utilization, Income Distribution and the Urban Informal Sector: An Open Economy Model, PERI Working Paper 35.

Schneider, F. and Enste, D. (2000) Shadow Economies: Size, Causes, and Consequences, The Journal of Economic Literature, 38, 77-114.

Sumata, C. (2000) Should the Informal Sector be Considered in LDC Economic Policy? School of Oriental and African Studies, University of London, Working Paper No. 90. 
Appendix 1: Data Sources

Size of Informal Sector (\% of GDP)

Size of informal output as a percentage of GDP, measured by physical input method based on electricity usage

Source: Kaufman, D and Kaliberda (1996) Integrating the Unofficial Economy into the dynamics of Post-Socialist Economies.

Exports of goods and services (\% of GDP)

Source: The World Bank Data Group

http://www.worldbank.org/data/countrydata/countrydata.html and World Development

Indicators Database, August 2005

Imports of goods and services (\% of GDP)

Source: The World Bank Data Group

http://www.worldbank.org/data/countrydata/countrydata.html and World Development

Indicators Database, August 2005

Trade $(\%$ of GDP)

Source: The World Bank Data Group

http://www.worldbank.org/data/countrydata/countrydata.html and World Development

Indicators Database, August 2005

Foreign direct investment, net inflows (\% of GDP)

Source: The World Bank Data Group

http://www.worldbank.org/data/countrydata/countrydata.html and World Development

Indicators Database, August 2005

Urban population (\% of total)

Source: The World Bank Data Group

http://www.worldbank.org/data/countrydata/countrydata.html and World Development

Indicators Database, August 2005

General government final consumption expenditure (\% of GDP)

Source: The World Bank Data Group

http://www.worldbank.org/data/countrydata/countrydata.html and World Development

Indicators Database, August 2005 
Table 1: Descriptive Statistics

\begin{tabular}{lccccc}
\hline Variables & Observations & Average & $\begin{array}{c}\text { Standard } \\
\text { Deviation }\end{array}$ & $\begin{array}{c}\text { Minimum } \\
\text { Value }\end{array}$ & $\begin{array}{c}\text { Maximum } \\
\text { Value }\end{array}$ \\
\hline $\begin{array}{l}\text { Size of Informal Sector (\% of } \\
\text { GDP) }\end{array}$ & 108 & 25.68 & 12.87 & 5.80 & 63.50 \\
\hline $\begin{array}{l}\text { Exports of goods and services } \\
\text { (\% of GDP) }\end{array}$ & 103 & 43.59 & 17.31 & 13.27 & 89.41 \\
\hline $\begin{array}{l}\text { Imports of goods and services } \\
\text { (\% of GDP) }\end{array}$ & 103 & 46.74 & 19.63 & 12.99 & 109.13 \\
\hline \begin{tabular}{l} 
Trade (\% of GDP) \\
\hline $\begin{array}{l}\text { Foreign direct investment, net } \\
\text { inflows (\% of GDP) }\end{array}$
\end{tabular} & 103 & 90.33 & 35.75 & 26.26 & 182.67 \\
\hline $\begin{array}{l}\text { Urban population (\% of total) } \\
\begin{array}{l}\text { General government final } \\
\text { consumption expenditure } \\
\text { (\% of GDP) }\end{array}\end{array}$ & 108 & 108 & 1.99 & -0.18 & 10.92 \\
\hline
\end{tabular}


Table 2: Empirical Results

\begin{tabular}{|c|c|c|c|}
\hline \multirow{3}{*}{ Independent Variables } & \multicolumn{3}{|c|}{ Dependent Variable } \\
\hline & 2.1 & 2.2 & 2.3 \\
\hline & $\begin{array}{l}\text { Informal Sector } \\
(\% \text { of GDP) }\end{array}$ & $\begin{array}{l}\text { Informal Sector } \\
\text { (\% of GDP) }\end{array}$ & $\begin{array}{l}\text { Informal Sector } \\
\text { (\% of GDP) }\end{array}$ \\
\hline Trade (\% of GDP) & $\begin{array}{l}0.08^{\star \star} \\
(0.03)\end{array}$ & & \\
\hline $\begin{array}{l}\text { Exports of goods and services } \\
\text { (\% of GDP) }\end{array}$ & & $\begin{array}{l}0.12^{\star \star} \\
(0.06)\end{array}$ & \\
\hline $\begin{array}{l}\text { Imports of goods and services } \\
\text { (\% of GDP) }\end{array}$ & & & $\begin{array}{l}0.16^{\star \star} \\
(0.07)\end{array}$ \\
\hline $\begin{array}{l}\text { Foreign direct investment, net } \\
\text { inflows ( } \% \text { of GDP) }\end{array}$ & $\begin{array}{l}1.47^{\star \star \star} \\
(0.53)\end{array}$ & $\begin{array}{l}1.54^{\star \star} \\
(0.67)\end{array}$ & $\begin{array}{l}1.36^{\star \star} \\
(0.61)\end{array}$ \\
\hline Urban population ( $\%$ of total) & $\begin{array}{l}0.91^{\star \star \star} \\
(0.17)\end{array}$ & $\begin{array}{l}0.91^{\star \star \star} \\
(0.17)\end{array}$ & $\begin{array}{l}0.91^{\star \star \star} \\
(0.17)\end{array}$ \\
\hline $\begin{array}{l}\text { General government final } \\
\text { consumption expenditure } \\
\text { (\% of GDP) }\end{array}$ & $\begin{array}{l}0.20 \\
(0.27)\end{array}$ & $\begin{array}{l}0.27 \\
(0.27) \\
\end{array}$ & $\begin{array}{c}0.14 \\
(0.27) \\
\end{array}$ \\
\hline Constant & $\begin{array}{c}-35.16^{\star \star \star} \\
(11.97)\end{array}$ & $\begin{array}{c}-35.30^{\star \star \star} \\
(10.64)\end{array}$ & $\begin{array}{l}-34.72^{\star \star \star} \\
(10.34)\end{array}$ \\
\hline Country fixed effect & Yes & Yes & Yes \\
\hline Year fixed effect & No & No & No \\
\hline $\mathrm{R}^{2}$ & 0.71 & 0.70 & 0.72 \\
\hline Observations & 102 & 102 & 102 \\
\hline
\end{tabular}


Table 3: Base Parameters

\begin{tabular}{cc}
\hline Parameters & Values \\
\hline$\alpha$ & 0.67 \\
$m$ & 0.75 \\
$m_{t l}$ & 0.75 \\
$\mu$ & 0.04 \\
$\mu_{t l}$ & 0.04 \\
$g$ & 0.08 \\
$k$ & 0.75 \\
$\gamma$ & 0.1 \\
$\gamma_{t l}$ & 0.15 \\
$\delta$ & 0.08 \\
$\delta_{t l}$ & 0.08 \\
\hline
\end{tabular}


Table 4: Impacts of Parametric changes on Formal and Informal shares of total Labor

\begin{tabular}{cccc} 
Cases & Parameter change & Formal Share & Informal Share \\
\hline Case $1 \mathrm{a}$ & $\gamma=.11, \gamma_{t l}=.13$ & Moderate decrease & Moderate increase \\
\hline Case $1 \mathrm{~b}$ & $\gamma=.125, \gamma_{t l}=.125$ & Moderate decrease & Moderate increase \\
\hline Case $1 \mathrm{c}$ & $\gamma=.13, \gamma_{t l}=.11$ & High decrease & High increase \\
\hline Case $2 \mathrm{a}$ & $\delta=.08, \delta_{t l}=.11$ & Low decrease & Low increase \\
\hline Case $2 \mathrm{~b}$ & $\delta=.11, \delta_{t l}=.08$ & Low decrease & Low increase \\
\hline Case 3a & $\alpha=.5$ & High decrease & High increase \\
\hline Case $3 \mathrm{~b}$ & $\alpha=.3$ & High decrease & High increase \\
\hline Case 3c & $\alpha=.8$ & Low increase & Low decrease \\
\hline Case $4 \mathrm{a}$ & $m=.6, m_{t l}=.8$ & Low decrease & Low increase \\
\hline Case $4 \mathrm{~b}$ & $m=.8, m_{t l}=.6$ & High decrease & High increase \\
\hline Case $4 \mathrm{c}$ & $m=.4, m_{t l}=.4$ & Moderate decrease & Moderate increase \\
\hline Case $5 \mathrm{a}$ & $\mu=.1, \mu_{t l}=.06$ & High decrease & High increase \\
\hline Case $5 \mathrm{~b}$ & $\mu=.06, \mu_{t l}=.1$ & Low increase & Low decrease \\
\hline Case $6 \mathrm{a}$ & $g=.05$ & Moderate decrease & Moderate increase \\
\hline Case $6 \mathrm{~b}$ & $g=.1$ & Moderate decrease & Moderate increase \\
\hline
\end{tabular}




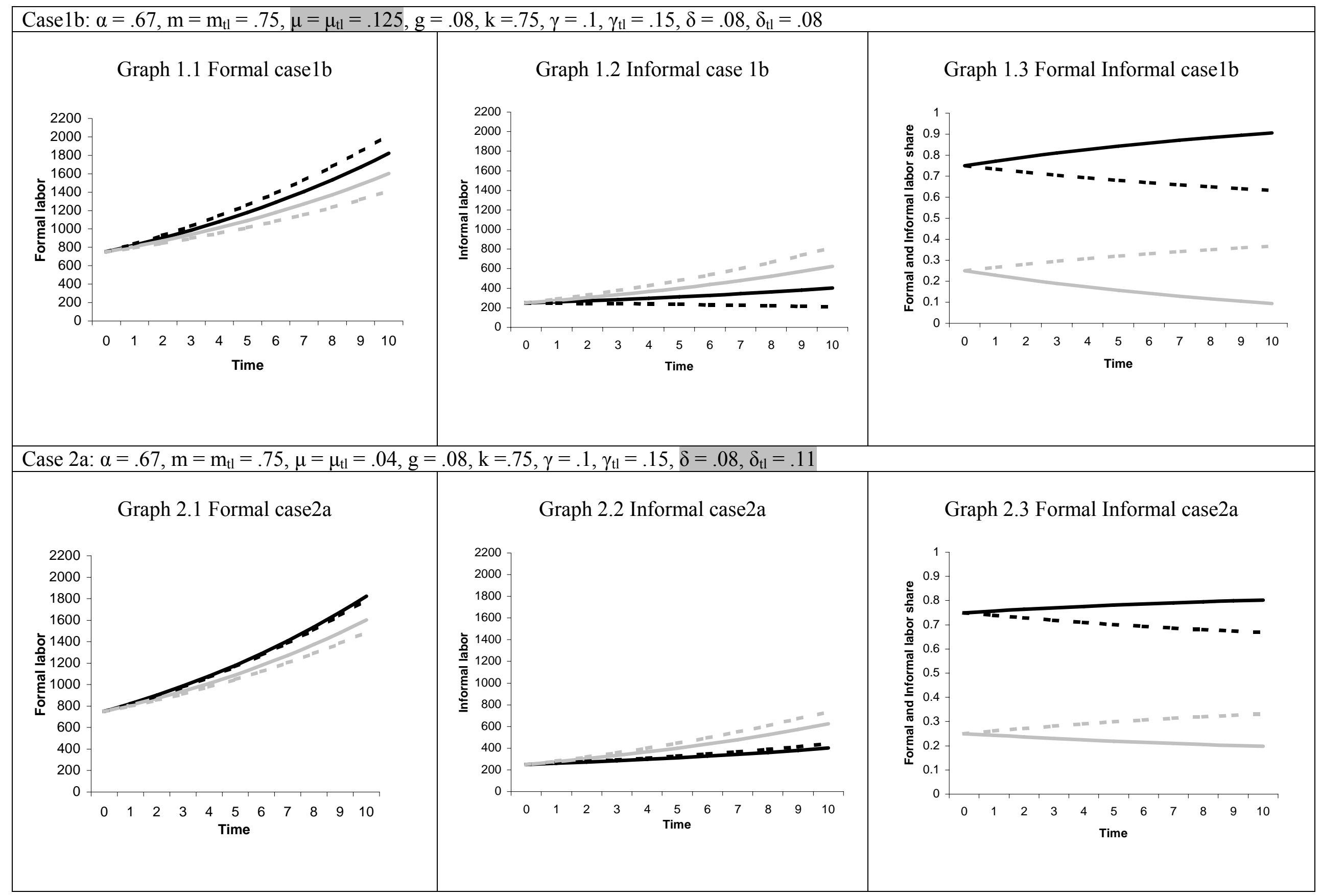



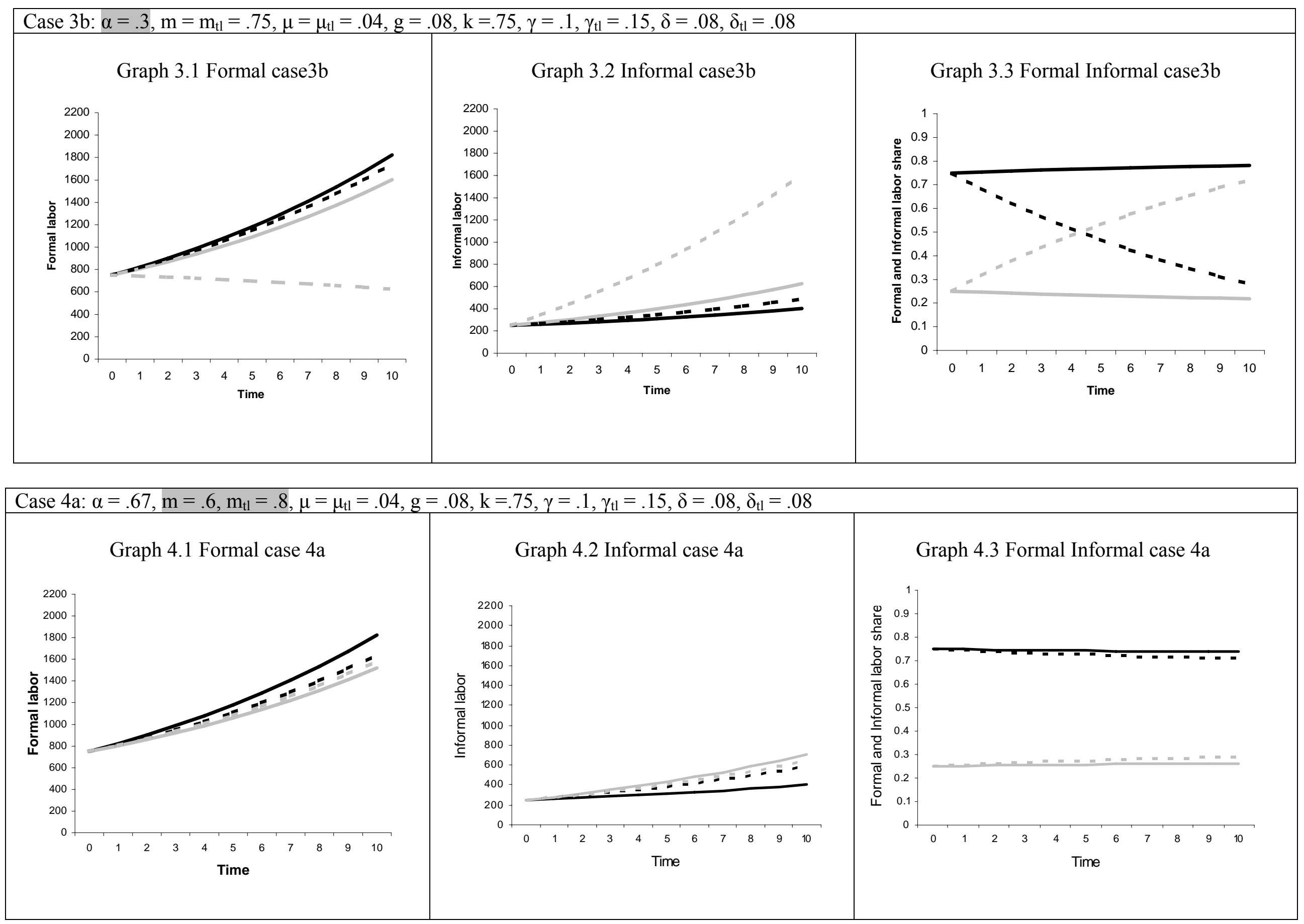

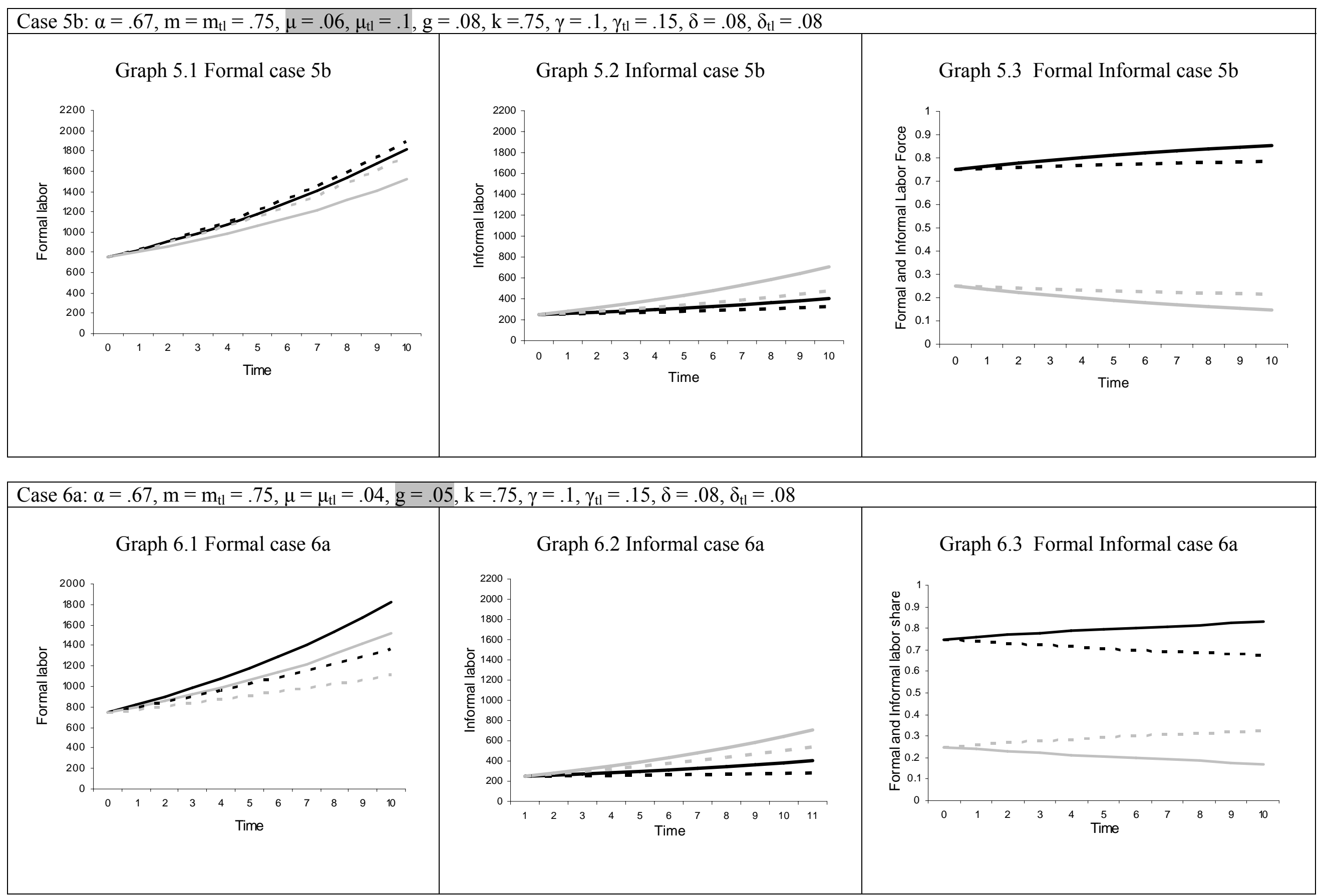
